\title{
Optimalisasi Lahan Pekarangan dengan Budidaya Tanaman Sayuran sebagai Salah Satu Alternatif dalam Mencapai Strategi Kemandirian Pangan
}

\author{
Rina Ekawati*, Lestari Hetalesi Saputri, Anna Kusumawati, Luci Paonganan, \\ Pantja Siwi V R Ingesti \\ Politeknik LPP Yogyakarta \\ *Corresponding Author: rne@polteklpp.ac.id
}

\begin{abstract}
ABSTRAK
Lahan pekarangan dapat menjadi salah satu alternatif sebagai lahan budidaya untuk memenuhi kebutuhan pangan rumah tangga, terutama tanaman sayuran. Tujuan kegiatan pengabdian ini adalah untuk memberikan pengetahuan kepada ibu-ibu anggota Kelompok Wanita Tani (KWT) Dusun Danen, Kelurahan Sumberadi, Kecamatan Mlati, Kabupaten Sleman, Provinsi Daerah Istimewa Yogyakarta tentang: (1) Pemilihan jenis media tanam yang tepat; (2) Kandungan nutrisi dalam sayuran; (3) Tahapan budidaya sayuran dalam polybag; (4) Manajemen kelompok tani; dan (5) Penghematan anggaran belanja rumah tangga dengan adanya budidaya sayuran di pekarangan rumah sendiri. Kegiatan pengabdian ini dilaksanakan pada tanggal 19 Januari 2020 dalam bentuk sosialisasi disertai dengan diskusi/tanya jawab, praktik budidaya dan evaluasi yang dilaksanakan dengan melibatkan 16 peserta. Evaluasi dilakukan tiga minggu setelah kegiatan dengan hasil yang menunjukkan bahwa peserta kegiatan sosialisasi dan penyuluhan telah mengetahui dengan baik kegiatan budidaya tanaman sayuran daun dan buah serta pemeliharaannya. Tanaman selada, paprika, cabai rawit, cabai merah, dan terung yang dibudidayakan telah tumbuh dengan baik hingga berumur 3 minggu setelah tanam (MST) ketika dilakukan evaluasi. Jika pemenuhan kebutuhan sayur rumah tangga dari pekarangan rumah $25 \%$, maka potensi penghematan belanja rumah tangga sekitar Rp 3.000,00 per hari.
\end{abstract}

Kata kunci: desa Sumberadi, pangan, pekarangan, sayuran

\begin{abstract}
Yard land can be an alternative for cultivation, especially for vegetables to meet household food needs. The purpose of this service activity is to provide knowledge to the women who are members of the Dusun Danen Farmer Women's Group (FWG), Sumberadi Village, Mlati District, Sleman Regency, Yogyakarta Special Region about: (1) Selection of the right type of planting media; (2) Nutritional content in vegetables; (3) Stages of cultivation of vegetables in polybags; (4) Farmer group management; and (5) saving on household expenditures by cultivating vegetables in one's own yard. This service activity was held on January 19, 2020, and was only a socialization activity accompanied by discussion/question and answer, direct practice, and evaluation which was carried out by involving 16 participants. The evaluation results did not use a quantitative questionnaire. Evaluation is only conducted once, namely after three weeks of activity. The results of the activity showed that the participants in the socialization and counseling activities were familiar with the activities of cultivating leaf and fruit vegetables and their maintenance. Cultivated lettuce, paprika, cayenne pepper, red chili, eggplant had grown well until they were three weeks after planting when evaluated. If the fulfillment of household vegetable needs from the yard of the house is $25 \%$, the potential for household spending savings is around Rp 3,000.00 per day.
\end{abstract}

Keywords: food, Sumberadi village, vegetables, yard

\section{PENDAHULUAN}

Peningkatan jumlah penduduk terus bertambah akan berdampak pada peningkatan permintaan akan kebutuhan manusia, terutama bahan pangan. Usaha pemenuhan bahan pangan tersebut juga akan mengalami keterbatasan karena beberapa penyebab antara 
lain perubahan iklim global dan penurunan luas lahan pertanian hingga 17\% (Kementerian Pertanian, 2015), penurunan produktivitas lahan, serta adanya serangan hama dan penyakit yang pada akhirnya akan menurunkan hasil panen. Oleh sebab itu, perlu adanya sebuah strategi dalam meningkatkan kecukupan, ketahanan, dan kemandirian pangan masyarakat.

Salah satu strategi dalam peningkatan kemandirian pangan adalah melalui pemanfaatan lahan pekarangan di sekitar rumah. Pekarangan tersebut dapat berada di depan, belakang atau samping rumah, tergantung seberapa luas sisa tanah yang tersedia setelah dipakai untuk bangunan utamanya. Lahan pekarangan memiliki potensi sebagai penyediaan bahan pangan keluarga (Ashari et al., 2012). Data statistik menunjukkan bahwa luasan lahan pekarangan di Indonesia mencapai 10,3 juta hektar. Apabila pekarangan tersebut dapat dioptimalkan fungsinya, maka diduga akan memiliki kontribusi terhadap kecukupan, ketahanan, dan kemandirian pangan masyarakat.

Budidaya tanaman sayuran di pekarangan rumah bukan merupakan hal yang baru dan sudah lama dilakukan terutama di pedesaan. Namun demikian, seiring berjalannya waktu kebiasaan tersebut semakin ditinggalkan dan banyak pekarangan di pedesaan justru tidak dimanfaatkan, dibiarkan terlantar dan tidak produktif. Seperti di Dusun Danen, Kelurahan Sumberadi, Kecamatan Mlati, Kabupaten Sleman, Yogyakarta, terdapat lahan pekarangan yang luas tetapi tidak dimanfaatkan. Kondisi tersebut mungkin disebabkan karena kurangnya pengetahuan dan pelatihan mengenai teknis budidaya tanaman dalam skala kecil (pekarangan) dan sebetulnya akan memiliki nilai lebih. Teknis budidaya seperti penyiapan media tanam dalam pot, budidaya tanaman dalam pot dengan pemeliharaannya, serta pot atau wadah tanaman dari bahan sekitar yang dapat digunakan untuk melakukan budidaya di pekarangan rumah. Salah satu pengembangan konsep Kawasan Rumah Pangan Lestari di Desa Rawa dan Desa Lumbungsari, Kecamatan Lumbung, Kabupaten Ciamis adalah memanfaatkan lahan pekarangan (Dwiratna et al., 2016). Oleh karena itu, pemanfaatan pekarangan untuk budidaya tanaman sayuran dapat digunakan sebagai salah satu alternatif untuk mencapai strategi ketahanan pangan keluarga.

Tanaman yang sering dibudidayakan di pekarangan antara lain cabai, terung, tomat, sawi, selada, kangkung, bayam, seledri, dan bawang prei. Jumlah jenis tanaman pangan (khususnya tanaman sayur, buah dan bumbu) lebih banyak dibudidayakan di pekarangan daripada jenis tanaman non-pangan (Azra et al., 2014). Hal tersebut menunjukkan bahwa potensi aneka tanaman hortikultura, khususnya tanaman sayuran masih menjadi tanaman utama yang dibudidayakan di lahan pekarangan. Adapun model penanaman bisa langsung di lahan pekarangan dan juga bisa menggunakan polibag, limbah plastik seperti gelas air mineral, dan botol air mineral sehingga budidaya aneka tanaman sayuran dapat menjadi alternatif bagi massyarakat yang memiliki lahan sempit.

Adapun tujuan dari kegiatan Pengabdian Kepada Masyarakat (PKM) ini yaitu memberikan/sharing tambahan pengetahuan pada ibu-ibu warga Dusun Danen tentang: (1) pemilihan jenis media tanam yang tepat, (2) kandungan nutrisi dalam sayuran, (3) tahapan budidaya sayuran dalam polybag dan (4) penghematan anggaran belanja rumah tangga dengan adanya budidaya sayuran di pekarangan rumah sendiri.

\section{METODE}

Pelaksanaan pengabdian ini hanya dilaksanakan dalam satu hari karena kegiatan ini bersifat insidental pada tanggal 19 Januari 2020. Lokasi yang dipilih yaitu Dusun Danen, Kelurahan Sumberadi, Kecamatan Mlati, Kabupaten Sleman, Provinsi Daerah Istimewa Yogyakarta. Kegiatan ini dilakukan dengan metode ceramah dan tanya jawab (diskusi) secara langsung tentang materi yang diberikan.

Setelah dilakukan ceramah dan tanya jawab, dilanjutkan dengan melakukan praktik langsung dalam pembuatan media tanam, pembibitan dan penanaman aneka tanaman sayuran. Kegiatan evaluasi dilakukan satu kali yaitu setelah tiga minggu dari praktek langsung. Evaluasi dilakukan dengan observasi tanaman sayuran setelah berumur tiga minggu setelah tanam dan tidak ada kuesioner yang bersifat kuantitatif. Adapun untuk rincian pelaksanaan pengabdian disajikan pada Tabel 1 .

\section{HASIL DAN PEMBAHASAN}

Kegiatan sosialisasi/penyuluhan dan praktik langsung dilaksanakan di salah satu rumah warga, tepatnya di rumah Ibu Ketua PKK. Target peserta untuk kegiatan penyuluhan ini 
Tabel 1. Rincian pelaksanaan kegiatan pengabdian masyarakat

\begin{tabular}{|c|c|c|c|}
\hline No. & Tema & Pemateri & Metode \\
\hline 1 & $\begin{array}{l}\text { Media tanam dalam polybag } \\
\text { sebagai upaya budidaya } \\
\text { tanaman sayuran }\end{array}$ & $\begin{array}{l}\text { Anna Kusumawati, } \\
\text { SP, M.Sc. }\end{array}$ & $\begin{array}{lrr}\text { Sosialisasi } & \text { dan } & \text { praktik } \\
\text { pembuatan } & \text { media } & \text { tanam di } \\
\text { polybag } & & \end{array}$ \\
\hline 2 & $\begin{array}{l}\text { Kandungan nutrisi sayuran } \\
\text { organik }\end{array}$ & $\begin{array}{lll}\text { Lestari } & \text { H.S, } & \text { ST., } \\
\text { M.Eng } & & \end{array}$ & $\begin{array}{l}\text { Sosialisasi kandungan nutrisi } \\
\text { pada sayuran organik }\end{array}$ \\
\hline 3 & $\begin{array}{l}\text { Budidaya aneka tanaman } \\
\text { sayuran di lahan pekarangan }\end{array}$ & $\begin{array}{l}\text { Rina Ekawati, SP., } \\
\text { M.Si }\end{array}$ & $\begin{array}{lrr}\text { Sosialisasi budidaya } & \text { aneka } \\
\text { tanaman sayur di lahan } \\
\text { pekarangan }\end{array}$ \\
\hline 4 & $\begin{array}{l}\text { Manajemen kelompok tani } \\
\text { dalam pengelolaan lahan } \\
\text { pekarangan }\end{array}$ & $\begin{array}{l}\text { Ir. Pantjasiwi V R I, } \\
\text { MP }\end{array}$ & $\begin{array}{l}\text { Sosialisasi tentang manajemen } \\
\text { kelompok tani dalam } \\
\text { pengelolaan lahan pekarangan }\end{array}$ \\
\hline 5 & $\begin{array}{l}\text { Penghematan anggaran } \\
\text { belanja rumah tangga } \\
\text { dengan bertanam aneka } \\
\text { sayuran di pekarangan } \\
\text { rumah }\end{array}$ & $\begin{array}{l}\text { Luci Paonganan, SE., } \\
\text { M.Acc }\end{array}$ & $\begin{array}{l}\text { Simulasi penghematan } \\
\text { anggaran belanja rumah tangga } \\
\text { berdasarkan hasil menanam } \\
\text { berbagai tanaman sayuran di } \\
\text { pekarangan rumah. }\end{array}$ \\
\hline
\end{tabular}

adalah 40 orang ibu-ibu anggota Kelompok Wanita Tani (KWT). Dalam pelaksanaannya hanya sekitar 16 orang yang berperan secara aktif atau hadir dalam kegiatan tersebut. Kegiatan evaluasi menggunakan hasil foto pengamatan (observasi) yang telah dijelaskan sebelumnya. Beberapa kegiatan penyuluhan yang telah dilakukan, antara lain:

\section{Penyuluhan peran media tanam dalam budidaya tanaman sayuran}

Adapun tujuan dari pelaksanaan penyuluhan peran media tanam dalam budidaya tanaman sayuran adalah untuk memberikan pemahaman kepada peserta kegiatan tentang pentingnya media tanam (dalam hal ini adalah tanah) dan kandungan unsur hara dalam tanah yang baik bagi tanaman, khususnya sayuran (Gambar 1). Selain pemaparan peran media tanam, juga dilakukan praktik pembuatan media tanam untuk sayuran (Gambar 2). Tanah sebagai media tanam memiliki peran penting dalam menentukan pertumbuhan tanaman yang tumbuh di atasnya. Media tanam bertugas menyediakan unsur hara yang dibutuhkan tanaman untuk hidup. Selain itu, media tanam juga berperan besar dalam menjaga tegaknya batang tanaman. Media tanam yang baik akan dapat mendukung pertumbuhan tanaman secara optimal. Tujuan dari pelaksanaan penyuluhan ini salah satunya adalah memberikan informasi kepada peserta kegiatan tentang pentingnya media tanam (dalam hal ini adalah tanah) dan kandungan unsur hara dalam tanah yang baik bagi tanaman, khususnya sayuran.

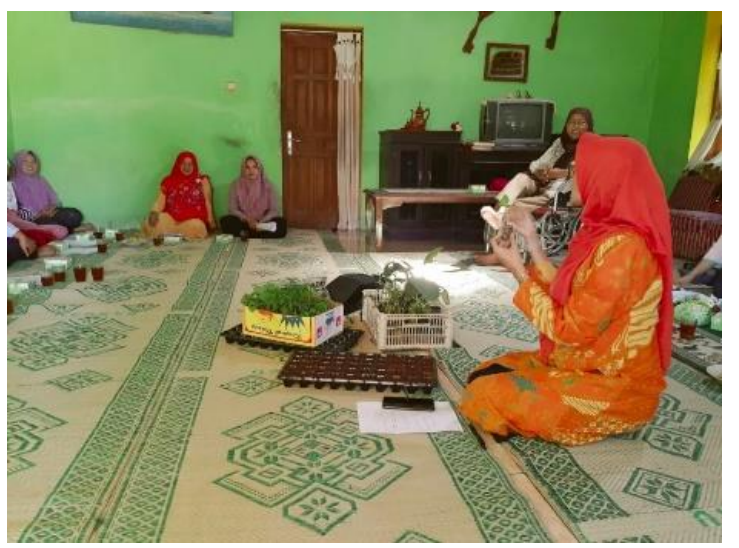

Gambar 1. Pemaparan peran media tanam

Sebelum adanya sharing pengabdian, terdapat peserta kegiatan yang belum mengetahui tentang bagaimana pemanfaatan pupuk kandang kambing sebagai campuran media tanam dan cara pengendalian penyakit pada tanaman cabai. Dengan adanya kegiatan ini, setelah pemaparan materi pengabdian dan diskusi secara langsung, pemahaman peserta kegiatan tentang pemilihan media tanam yang baik untuk budidaya tanaman sayuran semakin bertambah, yang ditunjukkan dari respon peserta. Respon dari peserta kegiatan sangat baik, terlihat dari antusias peserta dalam mendengarkan materi yang diberikan dan keaktifan dalam bertanya tentang bagaimana pemanfaatan pupuk kandang yang dapat dijadikan sebagai campuran sebagai media tanam.

Kegiatan budidaya tanaman sayuran memerlukan media tanam yang baik agar pertumbuhannya optimal. Untuk dapat memberikan daya dukung pertumbuhan sayur 
yang baik, media tanam (tanah) haruslah diolah terlebih dahulu, agar kesuburannya baik. Kesuburan tanah mencakup tiga hal, yaitu kesuburan secara fisika, kimia, dan biologi. Sifat fisika yang dapat memberikan pertumbuhan yang baik adalah jika tanah memiliki porositas yang cukup, aerasi yang baik, berat volume (kepadatan) tanah yang cukup sehingga diharapkan pertumbuhan akar yang berperan dalam mengambil unsur hara dan air dapat maksimal.

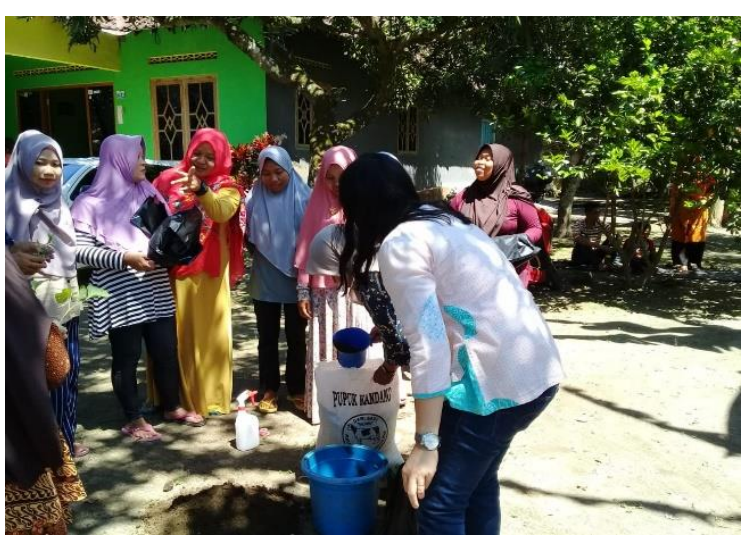

Gambar 2. Pembuatan media tanam

Sifat kimia yang baik untuk pertumbuhan sayur antara lain memiliki $\mathrm{pH}$ tanah yang netral, kandungan bahan organik (BO) yang cukup, serta ketersediaan hara yang optimal untuk pertumbuhan tanaman. Unsur hara yang dibutuhkan tanaman sayuran dalam jumlah atau kuantitas banyak antara lain Nitrogen $(\mathrm{N})$, Phospor (P), Kalium (K), Calcium (Ca), Magnesium (Mg) dan Sulfur (S), yang kita kenal sebagai unsur hara makro. Tanaman juga membutuhkan unsur hara mikro seperti Boron (B), Cuprum $(\mathrm{Cu})$, Chlor $(\mathrm{Cl})$, Besi $(\mathrm{Fe})$, Mangan (Mn), yang dibutuhkan dalam jumlah sedikit. Jika unsur hara mikro diberikan terlalu berlebihan, maka akan mengganggu pertumbuhan tanaman. Sebaliknya, jika unsur hara makro diberikan dalam jumlah yang sedikit, maka pertumbuhan tanaman tidak akan maksimal. Nitrogen merupakan faktor kunci dalam menentukan hasil tanaman yang berkelanjutan (Yang et al., 2019) terutama nitrat karena merupakan sumber utama $\mathrm{N}$ untuk tanaman (Robinson et al., 2011). Nitrogen dibutuhkan tanaman karena memiliki peran dalam pembentukan klorofil, pertumbuhan batang, cabang dan daun, sehingga memiliki peran besar dalam proses fotosintesis (Leghari et al., 2016). Hara $\mathrm{P}$ merupakan hara penting kedua setelah nitrogen. Fosfor berperan dalam pertumbuhan sel, pembentukan akar, pembentukan biji, buah, dan bunga. Selain itu, fosfor juga memiliki peran sebagai penyusun enzim dan ATP yang memiliki peran dalam transfer energi. Kalium memiliki peran dalam pembentukan protein, mengatur pergerakan stomata, serta memperkuat tegaknya batang. Peran lain $\mathrm{K}$ yaitu berperan dalam sintesa karbohidrat dan zat gula tanaman. Ketersediaan unsur hara $\mathrm{N}, \mathrm{P}$ dan $\mathrm{K}$ di dalam biasanya tanah rendah. Lokasi pengabdian ini memiliki tipe tanah yang muda dan belum berkembang lanjut. $\mathrm{pH}$ tanahnya berkisar masam sehingga ketersediaan haranya rendah. Untuk dapat dilakukan budidaya dengan baik, maka pengelolaan lahan harus dilakukan terlebih dahulu seperti pemberian kapur. Pemberian kapur saat pengolahan tanah memiliki peran dalam meningkatkan $\mathrm{pH}$ tanah. Jika $\mathrm{pH}$ tanah menjadi netral, maka ketersediaan hara akan semakin meningkat. Hal ini dikarenakan ketersediaan hara selain dipengaruhi oleh ketersediaan sumber haranya, $\mathrm{pH}$ tanah juga memiliki peran dalam mempengaruhi ketersediaannya. Selain kapur, pemberian pupuk baik NPK atau urea-SP-36 dan $\mathrm{KCl}$ dirasa perlu sebagai sumber tambahan hara agar pertumbuhan sayuran lebih baik.

\section{Penyuluhan tentang manfaat dan kandungan gizi sayuran untuk kesehatan manusia}

Penyuluhan ini bertujuan untuk memaparkan tentang manfaat dan kandungan gizi sayuran untuk kesehatan manusia (Gambar 3). Pada kegiatan ini, budidaya sayuran yang dilakukan dalam polybag menggunakan bibit selada, paprika, cabai rawit, cabai merah, terung, benih kubis merah dan bibit buah pepaya. Ratarata pemanfaatan sayuran adalah untuk sumber vitamin, mineral, dan serat. Selain itu, kandungan dalam sayuran adalah energi, protein, karbohidrat, lemak, dan bagian yang dapat dimakan (edible part).

Pada kegiatan penyuluhan ini, tanaman sayuran yang ditanam antara lain terung, cabai, selada, dan paprika. Tanaman-tanaman tersebut sangat berpotensi untuk dibudidayakan karena dapat memenuhi kebutuhan gizi sayuran (Muldiana \& Rosdiana, 2017). Salah satu golongan sayuran yang diambil/dipanen bagian buahnya adalah terung ungu yang memiliki kandungan phosphor, kalori, hidrat arang, vitamin A, B dan C. Sayuran buah tersebut juga memiliki kandungan bioaktif solanine, solasodine dan alkaloid sehingga dapat 
digunakan sebagai tanaman obat. Terung ungu biasanya dikonsumsi sebagai sayuran matang.

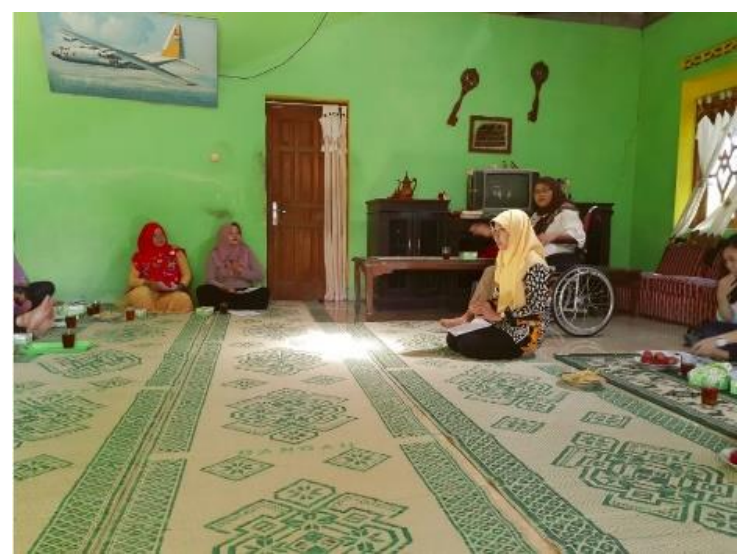

Gambar 3. Pemaparan kandungan gizi sayuran

Pepaya memiliki kandungan senyawa bioaktif, seperti: tanin, steroid, alkaloid dan minyak atsiri. Bagian biji merupakan 14,3\% dari total buah pepaya yang mengandung senyawa steroid, tinggi asam lemak tak jenuh berupa asam oleat dan palmitat (Satriyasa \& Pangkahila, 2010).

Vitamin $\mathrm{C}$ dan $\beta$-karoten adalah kandungan utama pada tanaman cabai rawit. Vitamin $\mathrm{C}$ dapat berfungsi sebagai antioksidan. Kandungan Ca dan $\mathrm{P}$ lebih tinggi daripada ikan segar. Jenis paprika merah mengandung vitamin C 2 kali lebih tinggi dan $\beta$-karoten 9 kali lebih tinggi dibandingkan paprika hijau.

Hasil dari penyuluhan yaitu meningkatnya pengetahuan dari peserta kegiatan tentang tanaman sayuran yang paling sering ditanam di pekarangan. Hal tersebut ditunjukkan dari para peserta kegiatan yang telah dapat melakukan atau mempraktekkan setiap tahapan dari penanaman sayuran di polybag. Hal tersebut juga ditunjukkan dengan rata-rata tanaman sayuran yang paling banyak dibudidayakan yaitu cabai, terung, tomat, dan sayuran daun seperti sawi, pakcoy, dan caisim. Tanaman-tanaman sayuran tersebut memang yang paling sering dimanfaatkan dan dikonsumsi oleh warga sekitar untuk pemenuhan kebutuhan akan nutrisi seperti vitamin, mineral, dan serat pangan yang bermanfaat bagi kesehatan tubuh.

\section{Penyuluhan teknik budidaya tanaman sayuran daun dan buah dalam polybag}

Adapun tujuan dari penyuluhan ini adalah lebih kepada bagaimana praktik langsung menanam berbagai jenis tanaman sayuran dalam polybag, beberapa tahapan dalam budidaya, serta cara pemeliharaannya di lahan pekarangan rumah yang ada. Selain praktik menanam sayuran (Gambar 4 dan 5), juga dilakukan praktik menanam bibit tanaman buah pepaya (Gambar 6).

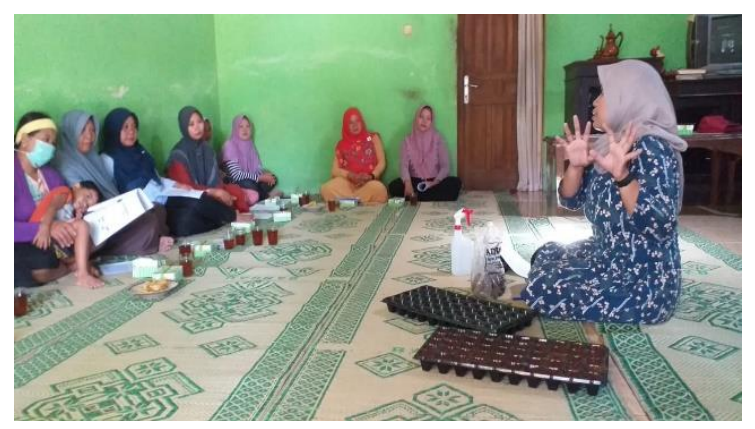

Gambar 4. Pemaparan teknik budidaya tanaman

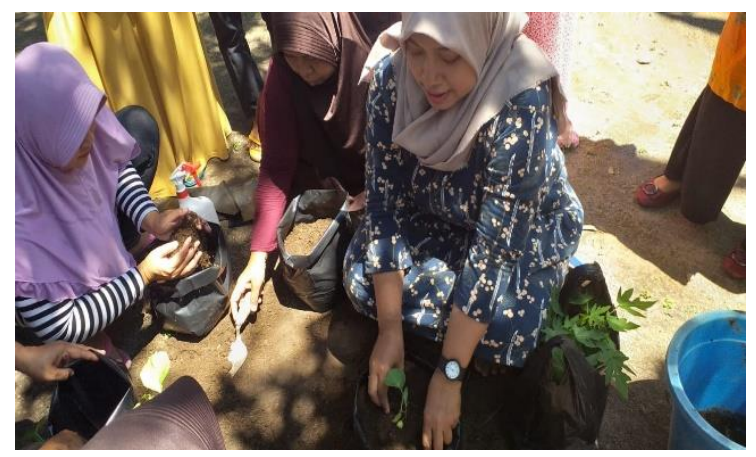

Gambar 5. Praktik penanaman sayuran

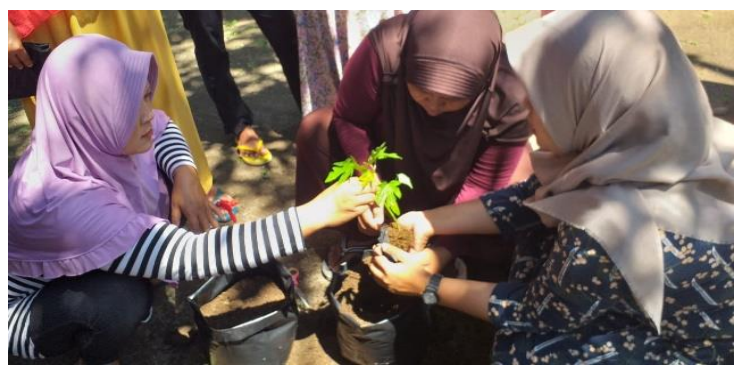

Gambar 6. Praktik penanaman bibit pepaya

Penggunaan wadah tanam merupakan cara budidaya sayuran yang mudah dan sering dilakukan. Salah satunya adalah penggunaan polybag atau pot. Selain polybag atau pot, bisa juga memanfaatkan wadah yang sudah tidak terpakai, seperti ember bekas, kaleng cat bekas, atau drum yang sudah tidak terpakai. Masyarakat yang tinggal di desa atau urban perkotaan yang memiliki atau bahkan tidak memiliki pekarangan, dapat menggunakan teknik budidaya tanaman sayuran menggunakan polibag/pot/wadah yang sudah tidak terpakai. Kegiatan menanam sayuran pada umumnya menggunakan jenis tanaman yang sering dimanfaatkan oleh masyarakat dalam skala rumah tangga, yaitu: kangkung, cabai, daun bawang, tomat, terung, seledri dan bayam. Masyarakat sebagian besar 
memanfaatkan tanaman sayuran daun dan buah (Setiawan \& Wijayanti, 2019), namun juga ada jenis tanaman sayuran dari golongan kacangkacangan, seperti: kacang panjang, koro, dan kecipir (Sarjiyah et al., 2016). Adapun beberapa kelebihan dalam bertanam sayuran dalam pot atau polybag, antara lain: (1) Mudah dilakukan dalam skala rumahan; (2) Mudah dalam pemeliharaannya; (3) Mengurangi resiko penularan penyakit melalui akar dan bagian lain karena tanaman ditanam dalam wadah terpisah; (4) Dapat menghemat lahan walau menanam dalam jumlah besar. Pot atau polibag dapat disusun di atas rak yang bersusun; (5) Penggunaan pupuk menjadi lebih dapat ditekan; dan (6) Memudahkan penanaman dengan jenis sayuran. Kegiatan bertanam sayuran dan buah salah satunya ditentukan oleh penggunaan polybag yang dilakukan oleh warga di Dukuh Bakalan, Desa Bata, Kecamatan Wonosari, Kabupaten Klaten dalam kegiatan penyuluhan (Pasir \& Hakim, 2014).

Untuk membudidayakan tanaman sayuran, kegiatan teknis budidaya tanaman menjadi suatu hal yang sangat penting. Kegiatan teknis budidaya dimulai dari persiapan media tanam, penyemaian benih, transplanting/pindah tanam, penanaman, pemeliharaan tanaman (pemupukan, irigasi/penyiraman, pengendalian organisme pengganggu tanaman/OPT), panen dan pascapanen. Kegiatan yang pertama kali dilakukan adalah penyiapan media tanam yang tepat dan sesuai dengan syarat tumbuh tanaman melalui olah tanah. Kegiatan berikutnya adalah memupuk yang bertujuan untuk menyediakan atau menambah unsur hara bagi tanaman. Pemupukan dapat menggunakan jenis pupuk anorganik dan/atau organik untuk menambah unsur hara makro maupun mikro yang tidak/kurang tersedia di dalam tanah. Selain itu, pemupukan juga dapat memperbaiki sifat fisik, kimia, dan biologi tanah serta meningkatkan kemampuan tanah dalam menyimpan air. Penyiraman/irigasi bertujuan untuk memenuhi kebutuhan air tanaman, baik pada kondisi water deficite ataupun water logging. Kondisi water deficite, tanaman akan mengalami kelayuan, kekeringan serta kematian. Sebaliknya, pada kondisi water logging, tanaman akan mengalami kekurangan oksigen sehingga dapat menghambat proses fisiologisnya. Selain itu, jika tanaman semakin tergenang akan menyebabkan bakteri/cendawan sebagai patogen menyerang akar sehingga lebih cepat busuk.
Penggunaan benih dalam tahapan penyemaian benih sebaiknya memakai benih yang telah memiliki ijin edar serta memiliki tingkat kemurnian yang tinggi, daya tumbuh/kecambah > 80\%, dan berasal dari tetua/induk yang sehat dan jelas. Setelah penyemaian berumur $\pm 3-4$ minggu, dilakukan transplanting/pindah tanam bibit ke lahan atau polybag yang ukurannya lebih besar. Penanaman dilakukan jika lahan/media tanam dalam wadah tanam sudah siap dengan memperhatikan komposisi/jenis serta jumlah media tanam yang digunakan. Media tanam yang telah siap/selesai dibuat lalu dimasukkan ke dalam polibag/dibuat bedengan jika di lahan.

Pemeliharaan tanaman meliputi: pemupukan, irigasi/penyiraman, pengendalian OPT/organisme pengganggu tanaman, baik secara mekanik, kimiawi maupun biologi/agen hayati yang disesuaikan dengan tingkat serangan OPT. Organisme penggangu tanaman yang dimaksud adalah hama, penyakit, dan gulma. Umur panen tanaman sayuran daun relatif singkat, yaitu sekitar 1-1,5 bulan. Panen dilakukan tepat waktu. Jika panen terlalu cepat atau terlambat, maka akan menurunkan kualitas/mutu dari sayuran tersebut. Selain itu, juga akan mempengaruhi mutu/kualitas nilai jual dari sayuran daun tersebut. Kegiatan pascapanen dilakukan untuk mencegah atau memperkecil kerusakan hasil. Adapun upaya untuk mengatasi hal tersebut, yaitu dapat dilakukan pengepakan yang baik, pengangkutan yang cepat, dan panen tepat waktu. Berikut ini adalah langkah-langkah praktis dalam membudidayakan sayuran daun maupun buah dalam polybag, antara lain:

\section{Pesemaian}

Benih disemai pada wadah/nampan/baki yang telah diisi dengan media tanam berupa campuran tanah dan kompos yang telah disiapkan sebelumnya. Setelah benih disemai/disebar, kemudian dilakukan penyiraman minimal sehari sekali pada waktu pagi/sore hari. Media tanam diusahakan tidak terlalu kering atau lembab. Jika media semai terlalu kering, benih tidak akan tumbuh, sedangkan jika media semai terlalu lembab benih akan lebih cepat busuk dan gagal tumbuh. Pesemaian dilakukan selama 3-4 minggu atau bibit telah memiliki daun berjumlah 3-4 helai, kemudian dilakukan tranplanting ke polybag ukuran sedang $(20 \mathrm{~cm} \times 20 \mathrm{~cm})$ atau besar. Gambar 1 menjelaskan tentang persiapan untuk tahap penyemaian benih dengan menggunakan wadah tanam berupa pot tray. 


\section{Persiapan media tanam}

Pembuatan media tanam yang paling mudah adalah dengan menggunakan tanah dan kompos dengan perbandingan 1:1 dan diaduk sehomogen mungkin. Komposisi media tanam tersebut dapat dicampur dengan arang sekam dan dimasukkan ke dalam polybag yang ukurannya lebih besar $(40 \mathrm{~cm}$ x $40 \mathrm{~cm})$.

\section{Penanaman}

Bibit sayuran yang telah tumbuh di semaian kemudian di-tranplanting/pindah tanam ke media tanam yang telah disiapkan sebelumnya. Kriteria bibit yang dipindah tanam telah dijelaskan pada tahap pesemaian sebelumnya. Penanaman harus menggunakan bibit yang sehat dan seragam pertumbuhannya.

\section{Pemeliharaan}

Kegiatan pemeliharaan tanaman meliputi: pemupukan, irigasi/penyiraman, pengendalian OPT/organisme pengganggu tanaman, baik secara mekanik, kimiawi maupun biologi/agen hayati yang disesuaikan dengan tingkat serangan OPT. Untuk tanaman sayuran, sebaiknya pengendalian secara kimiawi dibatasi dan dianjurkan menggunakan pengendalian secara biologis/penggunaan agen hayati.

\section{Panen}

Sayuran daun dan buah memiliki umur panen yang berbeda. Jenis sayuran daun dipanen pada umur $1-1.5$ bulan setelah transplanting. Selada dapat dipanen pada umur \pm 2 bulan setelah transplanting. Panen dilakukan dengan cara mengambil daun dengan batangnya, buah, atau mencabut sampai ke akar tanaman kemudian dibersihkan. Tanaman sayuran dengan bagian buah yang dipanen, contoh cabai merah dapat dipanen dengan interval panen 2-3 hari sekali pada umur 70-80 hari setelah tanam (Edi \& Bobihoe, 2010).

Hasil dari praktik penanaman sayuran dilakukan secara langsung berupa hasil foto pengamatan tanaman setelah berumur tiga minggu setelah tanam. Pada dasarnya peserta kegiatan juga antusias dalam praktik langsung menanam sayuran yang dilakukan di depan rumah peserta. Para peserta kegiatan juga terlihat telah dapat melakukannya dengan baik. Pada akhir kegiatan praktik langsung, peserta juga mengajukan pertanyaan terkait dengan peletakan polybag. Sayuran daun yang telah ditanam di polybag kemudian diletakkan di tempat yang sejuk dan cukup mendapatkan cahaya matahari.

\section{Penyuluhan tentang manajemen kelompok tani}

Kelompok tani merupakan kumpulan petani/peternak/pekebun yang dibentuk atas dasar kesamaan kondisi lingkungan (sosial, ekonomi, sumber daya), kesamaan kepentingan, dan keakraban untuk meningkatkan dan mengembangkan usaha anggotanya (Direktorat Jenderal Prasarana dan Sarana Pertanian, 2015). Pentingnya kelompok bagi kehidupan manusia bertumpu pada kenyataan bahwa manusia adalah makhluk sosial yang secara alami manusia tidak dapat hidup sendiri. Menurut Peraturan Menteri Pertanian No.67/Permentan/SM.050/12/2016, peran kelompok tani dikelompokkan menjadi tiga, yaitu sebagai wahana belajar, wahana kerja sama dan unit produksi. Kelompok tani dapat digunakan sebagai salah satu usaha untuk meningkatkan tingkat kesejahteraan petani melalui pengelolaan usahatani secara bersamaan.

Manajemen merupakan sebuah proses dalam rangka mencapai suatu tujuan organisasi dengan cara bekerja secara bersama-sama dengan orang-orang dan sumber daya yang dimiliki organisasi. Kelompok tani merupakan kesatuan dari masyarakat yang terbentuk untuk mencapai suatu tujuan secara berkelompok dengan memiliki kesadaran untuk saling tolongmenolong. Upaya memberdayakan kelompok tani diperlukan dalam pengelolaan kelompok yang dilakukan dari, oleh dan untuk petani (Salmon, 2017). Pada dasarnya manajemen kelompok tani meliputi empat pokok penting yakni perencanaan (planning), pengorganisasian (organizing), pelaksanaan (actuating) dan evaluasi (evaluating) yang semuanya ini diharapkan dapat dilakukkan oleh kelompok tani sendiri. Kelompok tani memiliki beberapa peran dalam manajemen penyuluhan (Nuryanti \& Swastika, 2011), antara lain: (1) Sebagai forum belajar berusahatani dan berorganisasi; (2) Sebagai wahana kerjasama; (3) Sebagai unit produksi usahatani; dan (4) Memberikan umpan balik tentang kinerja suatu teknologi.

Pada dasarnya ibu-ibu anggota KWT telah memiliki perencanaan terkait dengan pemanfaatan lahan pekarangan dan telah disampaikan dalam pertemuan anggota KWT. Namun demikian, belum terlaksana karena adanya keterbatasan sumber daya manusia, khususnya ibu-ibu anggota KWT yang belum memiliki minat yang tinggi terhadap program pemanfaatan lahan pekarangan yang telah direncanakan sebelumnya sehingga tidak bisa dilakukan evaluasi akhir secara kuantitatif. 


\section{Penyuluhan tentang manajemen anggaran belanja rumah tangga dengan bertanam aneka sayuran di pekarangan rumah}

Pemanfaatan pekarangan di sekitar rumah merupakan salah satu cara dalam pemenuhan kebutuhan pangan untuk peningkatan kesejahteraan masyarakat dan efisiensi kebutuhan skala rumah tangga (Diwanti, 2018). Pada kegiatan pengabdian masyarakat, ibu-ibu rumah tangga diberikan materi berupa motivasi untuk dapat memulai bertanam sayuran di pekarangan rumah dengan tekun dan telaten agar dapat menghemat pengeluaran (Gambar 7). Jika dilihat dari sisi ekonomi, dengan mengusahakan sayur secara mandiri dapat menghemat anggaran belanja rumah tangga dalam jumlah yang cukup signifikan.

Sayur-mayur merupakan salah satu menu pokok yang selalu hadir dalam hidangan keluarga Indonesia termasuk ibu-ibu di Desa Danen. Belanja sayur-sayuran menjadi pos kebutuhan yang selalu hadir dalam anggaran dan daftar belanja sehari-hari para ibu rumah tangga. Berdasarkan diskusi, beberapa ibu rumah tangga dalam satu hari rata-rata mempunyai pengeluaran sekitar Rp 15.000,00 per hari untuk membeli sayur-sayuran. Pengeluaran ini dalam satu bulan akan berjumlah Rp. 450.000,00 dan dalam setahun berjumlah Rp. 5.400.000,00. Angka ini menunjukkan pengeluaran untuk sayur-sayuran setiap hari jika diakumulasikan dalam satuan bulan dan tahun maka jumlahnya cukup signifikan.

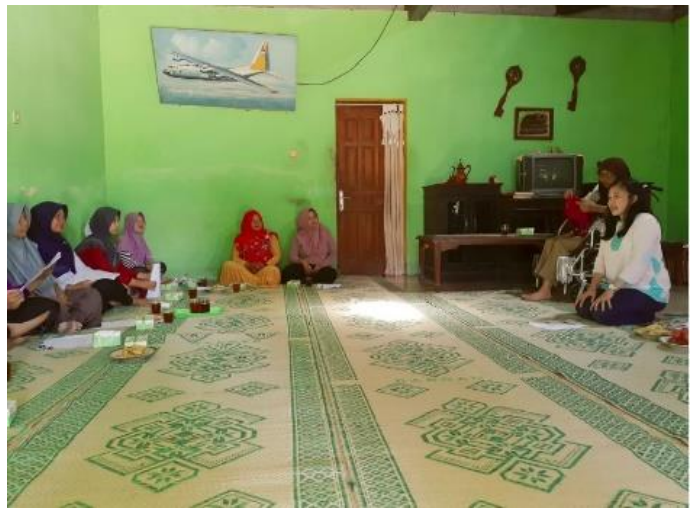

Gambar 7. Pemaparan manajemen anggaran belanja

Di tengah kebutuhan rumah tangga yang semakin mahal dan banyaknya kebutuhan rumah tangga yang harus dipenuhi seperti pendidikan anak, kesehatan, sandang dan perumahan maka akan sangat bijak apabila ibu-ibu rumah tangga dapat menghemat pengeluaran belanja seharihari tanpa mengurangi kualitas dan gizi menu yang dihadirkan bagi keluarga tercinta. Hal ini dapat dicapai dengan bertanam sayur-sayuran di pekarangan rumah untuk konsumsi keluarga sehari-hari. Dengan memanfaatkan lahan pekarangan rumah serta media tanam yang tersedia di sekitar lingkungan Desa Danen maka pengeluaran untuk belanja sayur-sayuran dapat dihemat.

Simulasi penghematan belanja rumah tangga jika ibu-ibu dapat memanfaatkan pekarangan rumah untuk menanam sayursayuran dapat dilihat pada Tabel 2. Apabila 25\% kebutuhan sayuran keluarga dapat dipenuhi dari bertanam sayuran pekarangan rumah, maka dalam sehari ibu-ibu dapat berhemat $\mathrm{Rp}$ 3.000,00 yang jika diakumulasikan dalam sebulan akan menghemat sebesar Rp 112.500,00 dan dalam setahun sebesar Rp 1.350.000,00. Jumlah anggaran yang dapat dihemat tersebut nantinya dapat dialokasikan untuk memenuhi kebutuhan rumah tangga lainnya. Apabila ibuibu dapat memenuhi seluruh kebutuhan sayuran (100\%) dari pekarangan rumah maka jumlah yang dapat dihemat juga lebih besar yakni bisa mencapai Rp 5.400.000,00 dalam setahun. Hal ini sejalan dengan temuan di Desa Bantarjati (Haryanti \& Sukmana, 2016) bahwa dengan adanya optimalisasi lahan pekarangan dapat mengurangi pengeluaran sehari-hari dan meningkatkan status gizi dalam keluarga.

Kegiatan menanam sayur-sayuran di pekarangan rumah sebagai bagian dari kegiatan sehari-hari dengan tekun dan telaten sehingga dapat berjalan secara terus-menerus, maka ibuibu tidak hanya dapat menghemat belanja rumah tangga tetapi juga telah berkontribusi nyata dalam upaya menciptakan ketahanan dan kemandirian pangan keluarga. Adanya pemanfaatan pekarangan di sekitar rumah untuk bertanam sayuran dapat menghasilkan sayuran yang dapat langsung dikonsumsi sendiri sehingga menurunkan jumlah pengeluaran belanja (Syamsi et al., 2019).

\section{Evaluasi}

Pada kegiatan ini hanya dilakukan evaluasi berupa hasil foto tanaman cabai, terung, paprika, selada dan papaya berumur 3 MST (minggu setelah tanam) yang telah dibudidayakan sejak kegiatan pengabdian dilakukan (Gambar 8). 
Tabel 2. Simulasi penghematan belanja rumah tangga dengan bertanam sayuran di pekarangan rumah

\begin{tabular}{cccc}
\hline $\begin{array}{c}\text { Persentase kebutuhan } \\
\text { sayuran dipenuhi dari } \\
\text { pekarangan rumah }(\%)\end{array}$ & $\begin{array}{c}\text { Jumlah } \\
\text { Penghematan dalam } \\
1 \text { hari }(\mathrm{Rp})\end{array}$ & $\begin{array}{c}\text { Jumlah } \\
\text { Penghematan dalam } \\
1 \text { bulan }(\mathrm{Rp})\end{array}$ & $\begin{array}{c}\text { Jumlah } \\
\text { Penghematan dalam } \\
1 \text { tahun }(\mathrm{Rp})\end{array}$ \\
\hline 25 & 3.750 & 112.500 & 1.350 .000 \\
50 & 7.500 & 225.000 & 2.700 .000 \\
75 & 11.250 & 337.500 & 4.050 .000 \\
100 & 15.000 & 450.000 & 5.400 .000 \\
\hline
\end{tabular}

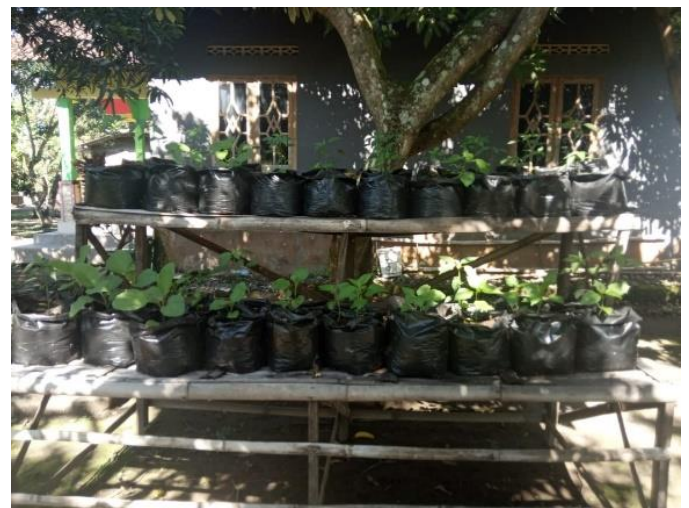

Gambar 8. Tanaman sayuran yang telah berumur 3 MST

Foto tersebut dikirimkan oleh Ketua KWT (Kelompok Wanita Tani) pada tanggal 4 Februari 2020, yang berarti tanaman sayuran telah berumur 3 MST (minggu setelah tanam). Ketua KWT Dusun Danen berkata bahwa, "Assalamualaikum, ibu tanamannya sekarang sudah besar dan subur, tapi yang kobis merah agak sulit tumbuh". Hal tersebut menunjukkan bahwa sebagian besar bibit tanaman sayuran yang diberikan pada kegiatan pengabdian yang kemudian ditanam, dapat tumbuh dengan subur, kecuali tanaman kubis merah yang pertumbuhannya kurang baik.

\section{KESIMPULAN}

Keseluruhan peserta kegiatan sosialisasi dan penyuluhan yaitu ibu-ibu anggota KWT yang dilaksanakan di Dusun Danen, Kelurahan Sumberadi, Kecamatan Mlati, Kabupaten Sleman, Provinsi Daerah Istimewa Yogyakarta telah mengetahui dan melakukan budidaya tanaman sayuran daun dan buah secara langsung sekaligus pemeliharaannya. Pengetahuan tersebut diperoleh dari praktik langsung penanaman sayuran. Tanaman sayuran (selada, paprika, cabai rawit, cabai merah, terung) yang dibudidayakan telah berumur 3 MST dan memiliki pertumbuhan yang subur, kecuali tanaman kubis merah. Jika pemenuhan sayuran dari pekarangan rumah sendiri sekitar $25 \%$, maka memiliki potensi penghematan belanja rumah tangga sekitar Rp 3.000,00/hari.

\section{UCAPAN TERIMA KASIH}

Ucapan terima kasih ditujukan kepada institusi Politeknik LPP yang telah memberikan dana untuk kegiatan pengabdian ini serta ibu-ibu anggota KWT Dusun Danen, Kelurahan Sumberadi, Kecamatan Mlati, Kabupaten Sleman, Provinsi Daerah Istimewa Yogyakarta.

\section{DAFTAR PUSTAKA}

Ashari, Saptana, \& Purwantini, T. B. (2012). Potensi dan prospek pemanfaatan lahan pekarangan untuk mendukung ketahanan pangan. Forum Penelitian Agro Ekonomi, 30(1), $13-30$. https://doi.org/10.21082/fae.v30n1.2012. 13-30

Azra, A. L. Z., Arifin, H. S., Astawan, M., \& Arifin, N. H. (2014). Analisis karakteristik pekarangan dalam mendukung penganekaragaman pangan keluarga di Kabupaten Bogor. Jurnal Lanskap Indonesia, 6(2), 1-12. https://doi.org/10.29244/jli.2014.6.2.1-12

Direktorat Jenderal Prasarana dan Sarana Pertanian. (2015). Pedoman pengembangan usaha agribisnis perdesaan TA 2015.

Diwanti, D. P. (2018). Pemanfaatan pertanian rumah tangga (pekarangan rumah) dengan teknik budidaya tanaman sayuran secara vertikultur. Jurnal Pengabdian Masyarakat: MARTABE, 1(3), 101-107.

Dwiratna, N. P. S., Widyasanti, A., \& Rahmah, D. M. (2016). Pemanfaatan lahan pekarangan dengan menerapkan konsep kawasan rumah pangan lestari. Dharmakarya: Jurnal Aplikasi Ipteks Untuk Masyarakat, 5(1), 19-22. https://doi.org/10.24198/dharmakarya.v5i 1.8873 
Edi, S., \& Bobihoe, J. (2010). Budidaya tanaman sayuran. Balai Pengkajian Teknologi Pertanian (BPTP) Jambi.

Haryanti, Y., \& Sukmana. (2016). Optimalisasi pemanfaatan lahan pekarangan dalam mendukung peningkatan gizi keluarga. Buletin Hasil Kajian, 6(06).

Leghari, S. J., Wahocho, N. A., Laghari, G. M., HafeezLaghari, A., MustafaBhabhan, G., HussainTalpur, K., Bhutto, T. A., Wahocho, S. A., \& Lashari, A. A. (2016). Role of nitrogen for plant growth and development: a review. Advances in Environmental Biology, 10(9), 209-219.

Muldiana, S., \& Rosdiana. (2017). Respon tanaman terong (Solanum malongena L.) terhadap interval pemberian pupuk organik cair dengan interval waktu yang berbeda. Prosiding Seminar Nasional 2017 Fakultas Pertanian UMJ "Pertanian Dan Tanaman Herbal Berkelanjutan Di Indonesia,” 155-162.

Nuryanti, S., \& Swastika, D. K. S. (2011). Peran kelompok tani dalam penerapan teknologi pertanian. Forum Penelitiaan Agro Ekonomi, 29(2), 115-128.

Pasir, S., \& Hakim, M. S. (2014). Penyuluhan penanaman sayuran dengan media polybag. Jurnal Inovasi Dan Kewirausahaan, 3(3), 159-163.

Robinson, N., Brackin, R., Vinall, K., Soper, F., Holst, J., Gamage, H., PaungfooLonhienne, C., Rennenberg, H., Lakshmanan, P., \& Schmidt, S. (2011). Nitrate paradigm does not hold up for sugarcane. PLoS ONE, 6(4). https://doi.org/10.1371/journal.pone.0019 045
Salmon, K. E. (2017). Penerapan fungsi manajemen pada kelompok tani Asi Endo di Desa Tewaen Kecamatan Amurang Barat Kabupaten MInahasa Selatan. AgriSosioEkonomi Unsrat, 13(3A), 259-270.

Sarjiyah, Samijo, G. S., \& Istiyani, E. (2016). Mewujudkan desa mandiri pangan melalui pengelolaan pekarangan. BERDIKARI, 4(1), 13-22.

Satriyasa, B. K., \& Pangkahila, W. I. (2010). Fraksi heksan dan fraksi metanol ekstrak biji pepaya muda menghambat spermatogonia mencit (Mus Musculus) jantan. Jurnal Veteriner, 11(1), 36-40.

Setiawan, A. N., \& Wijayanti, S. N. (2019). Desa mandiri pangan berbasis pekarangan di Donokerto, Turi, Sleman, DIY. Adimas : Jurnal Pengabdian Kepada Masyarakat, $3(2)$,

16-22. https://doi.org/10.24269/adi.v3i2.1828

Syamsi, F., Anggraini, D., \& Ramses, R. (2019). Pemanfaatan pekarangan rumah untuk bertanam sayuran organik dalam rangka mewujudkan kemandirian pangan keluarga. Minda Baharu, 3(1), 9-15. https://doi.org/10.33373/jmb.v3i1.1877

Yang, Y., Gao, S., Su, Y., Lin, Z., Guo, J., Li, M., Wang, Z., Que, Y., \& Xu, L. (2019). Transcripts and low nitrogen tolerance: Regulatory and metabolic pathways in sugarcane under low nitrogen stress. Environmental and Experimental Botany, 163(April), 97-111. https://doi.org/10.1016/j.envexpbot.2019. 04.010 